\title{
The mediating effect of strategic orientation, innovation capabilities and managerial capabilities among exploration and exploitation, competitive advantage and firm's performance
}

\author{
El efecto mediador de la orientación estratégica, las capacidades de \\ innovación y las capacidades de gestión entre la exploración y la explotación, \\ la ventaja competitiva y el desempeño de la empresa
}

\author{
Jorge António Barbosa Ferreira * , Arnaldo Coelho, \\ Laodicéia Amorim Weersma \\ Universidade de Coimbra, Portugal
}

Received November 29, 2017; accepted September 10, 2018

Available online November 25, 2018

\begin{abstract}
This study employs a dynamic capability (hereafter DCs) perspective to examine the relationships among strategic orientation (SO), innovation capability (IC), managerial capabilities (MC) and exploration and exploitation capabilities on competitive advantage (CA) and firm's performance. This paper proposes that the role of exploration and exploitation capabilities in these relationships differs between the three dimensions of strategy orientation (leadership cost-based strategies, and differentiation-based strategies and product-market scope) and performance. Modelling structural analysis was used to test the hypotheses in a sample of 387 Portuguese SME's firms. The empirical findings indicate that innovation capability, managerial capabilities and strategic orientation positively mediate the relationship between exploration and exploitation capabilities and performance, whereas strategic orientation affects competitive advantage and performance. Finally, the study provides a discussion on the theoretical and managerial implications and directions for future research.
\end{abstract}

JEL code: M00

Keywords: Dynamic Capabilities; Exploitation and Exploration capabilities; Strategic Orientation, Innovation Capabilities, Managerial capabilities; Competitive Advantage and Performance.

\footnotetext{
* Corresponding author.

E-mail address: jorge.ferreira065@gmail.com (J.A. Barbosa Ferreira)

Peer Review under the responsibility of Universidad Nacional Autónoma de México.
} 


\section{Resumen}

Este estudio emplea una perspectiva de las capacidades dinámicas (en adelante DC) para examinar las relaciones entre la orientación estratégica (SO), la capacidad de innovación (IC), las capacidades de gestión (MC) y las capacidades de exploración y explotación, sobre la ventaja competitiva (CA) y el desempeño de la empresa. Este estudio propone que el papel de las capacidades de exploración y explotación en estas relaciones difiere entre las tres dimensiones de la orientación estratégica (estrategias basadas en los costos de liderazgo y estrategias basadas en la diferenciación y estrategias de producto/mercado) y el desempeño. Se utilizó el análisis de ecuaciones estructurales para testar las hipótesis en una muestra de 387 PYME portuguesas. Los resultados empíricos indican que la capacidad de innovación, las capacidades de gestión y la orientación estratégica median positivamente la relación entre las capacidades de exploración y explotación y el desempeño, mientras que la orientación estratégica afecta la ventaja competitiva y el desempeño. Finalmente, el estudio proporciona una discusión sobre las implicaciones teóricas y de gestión y las direcciones para futuras investigaciones.

Código JEL: M00

Palabras clave: capacidades dinámicas; capacidades de explotación y exploración; orientación estratégica, capacidades de innovación, capacidades gerenciales; ventaja competitiva y desempeño.

\section{Introduction}

The dynamic capability-based view dynamic capabilities of competitive strategy attempt to explain why some firms gain competitive advantage in continually changing environments (Eisenhardt \& Martin, 2000; Teece, Pisano, \& Shuen, 1997). Dynamic capabilities assign a prominent role to the firm's strategic leadership in the nurturing and building of dynamic capabilities critical to the value generation process.

Although early research on dynamic capabilities suggests a link to competitive advantage (Griffith \& Harvey, 2001; Teece, et al., 1997), there has been lack of agreement on the nature of this relationship. Cepeda and Vera (2007) state that the link between dynamic capabilities and competitive advantage tautological as researchers have tended to claim dynamic capabilities post hoc, inferring their existence from successful organizational outcomes such as profitability and growth.

Eisenhardt and Martin (2000, p. 1107) provide an alternate view and argue that 'dynamic capabilities are the organizational and strategic routines by which firms achieve new resource configurations as markets emerge, collide, split, evolve, and die'. Eisenhardt and Martin (2000), Teece et al. (1997), Zollo and Winter (2002) recognize dynamic capabilities to be a key factor in firm competitiveness through sensing, seizing and reconfiguring (Teece et al., 1997), whereas organizational ambidexterity is responsible for the simultaneous management of exploratory and exploitative activities, thus helping to manage rapid environmental change (O’Reilly and Tushman, 1996; Li et al., 2008; Raisch et al., 2009).

The relationship between the concepts of organizational ambidexterity and dynamic capabilities remains relatively unexplored. A better understanding of this relationship is necessary to comprehend the effect it has on firm performance. This paper makes several contributions to the theories of dynamic capabilities and organizational ambidexterity. It has been confirmed that dynamic capabilities have no direct impact on firm competitive advantage. Several researchers (Eisenhardt and Martin, 2000; Helfat, 1997; Liu et al. 2014; Teece et al., 1997; Teece, 2007) analysed dynamic capabilities' impact on firm competitive advantage. Each 
of these studies, though using different variables, indicate that the relation between dynamic capabilities and firm competitive advantage is indirect. Accordingly, it is necessary to identify strategic orientation and managerial and innovation capabilities that can have a mediating effect on this relation. Thus, previous studies (He and Wong, 2004; Jansen et al., 2006) have confirmed innovations to be a source of competitive advantage.

Prior studies in this area have mainly focused on firms operating in developed markets, and little is known about what dynamic capabilities are, or their relationship with performance in transition economies. Thus, the study uses Portugal as a testing ground for the universality of the generated theory for three reasons: Portugal's size in the global economy, because it is in a process of internationalization, and its insertion in a European context.

To address these research gaps, this study explores the definition and effects of DCs, and the specifically exploitative and the explorative vision of the firm, and the mediating role of Strategic orientation, Managerial capabilities and the IC and their impact on the firm's performance. As such, this research contributes to existing literature by entailing the new research context, Portugal, and clarifies the debates, to help understand the effect of DCs and the role of environmental dynamism.

\section{Conceptual background}

Dynamic Capabilities based view

The concept of dynamic capabilities receives significant attention within the field of strategic management. Dynamic capabilities have been analysed from several perspectives and using various approaches. Despite more than a decade of research on the concept, many critical and unresolved issues exist. Several researchers (Eisenhardt and Martin, 2000; Helfat and Peteraf, 2003, 2009; Peteraf et al., 2013; Schilke, 2014; Teece et al., 1997; Teece, 2007; Winter, 2003) developed a field of dynamic capabilities representing a range of views of the concept.

Dynamic capabilities can be defined as competencies (Barreto, 2010; Adner and Helfat, 2003), abilities (Martin, 2011, Barreto, 2010; Helfat and Winter, 2011), capabilities (Barreto, 2010; Teece et al., 1997; Zollo and Winter, 2002), capacities (Martin, 2011), processes (Eisenhardt and Martin, 2000) and routines (Barreto, 2010). Originating from the Schumpeterian logic of creative destruction, dynamic capabilities enable firms to integrate, build, and reconfigure their resources and competencies in the face of changing business environments (Teece et al., 1997). In this sense, dynamic capabilities are perceived as strategic options that allow firms to renew their existing operational capabilities when the opportunity or need arises (Pavlou \& El Sawy, 2006). They are directed towards strategic change and aligning the organization with the environment (Zahra, Sapienza, \& Davidsson, 2006). Despite the relatively novel inception of the dynamic capabilities notion, researchers have subsequently refined and expanded the conceptualization (Eisenhardt \& Martin, 2000; Helfat et al., 2007; Teece, 2007). Empirical studies that embark on the quest of unravelling the causal mechanisms through which dynamic capabilities act, not that their value is amplified under conditions of increased environmental uncertainty (Wu, 2007; Drnevich \& Kriauciunas, 2011; Pavlou \& El Sawy, 2011). Additionally, the DCV has been found to be more appropriate in explaining competitive performance gains than the RBV, something that is reflected in recent meta-analyses of past empirical studies (Pezeshkan, Fainshmidt, Nair, Frazier, \& Markowski, 2016; Fainshmidt, Pezeshkan, Lance 
Frazier, Nair, \& Markowski, 2016). Ergo, dynamic capabilities help sustain a firm's evolutionary fitness and prevent rigidities (Protogerou, Caloghirou, \& Lioukas, 2012; Girod \& Whittington, 2016; Mikalef and Pateli, 2017).

Dynamic capabilities, which are underpinned by organizational routines and managerial skills, are the firm's ability to integrate, build, and reconfigure internal competences to address, or in some cases to bring about, changes in the business environment (Teece et al., 1997; Teece, 2007; Teece, 2018).

Eisenhardt and Martin (2000) perceived dynamic capabilities as specific strategic processes. In general, a dynamic capabilities concept is usually regarded as an extension of the recoursebased view (Schilke, 2014). A firm's dynamic capabilities are its ability "to renew itself in the face of a changing environment by changing its set of resources" (Danneels, 2010, p. 1). They can be disaggregated into these capabilities: "(1) to sense and shape opportunities and threats, (2) to seize opportunities, and (3) to maintain competitiveness through enhancing, combining, protecting, and when necessary, reconfiguring the business enterprise's intangible and tangible assets" (Teece, 2007, p. 1319; Wilden et al., 2013). Romme et al. (2010) stated that dynamic capabilities can enhance an organization's ability to change and adapt to new environmental requirements. In a changing environment, therefore, dynamic capabilities are a necessary resource to sustain competitive advantage (Haleblian et al., 2012; Kuo et al., 2017; Braganza et al., 2017). Zollo and Winter (2002, p.344) propose "dynamic capabilities emerge from the co-evolution of tacit experience accumulation processes with explicit knowledge articulation and codification activities".

While the recourse-based view involves issues addressed to existing resources of the firm, the dynamic capabilities view concerns the reconfiguration of existing recourses and the creation of the new recourses (Helfat and Peteraf, 2003; Schilke, 2014). According to Helfat and Peteraf (2003), the recourse-based view explains the differences among competing firms, which appear because of the recourses that firms have. These differences also have a respective impact on firm competitive advantage. In this way, dynamic capabilities become critical, as they promote changes in the existing firm's recourse base (Helfat and Peteraf, 2003; Schilke, 2014) and thus lead to competitive advantage for the firm.

\section{Antecedents of Exploitation and Exploration}

The concepts of exploration and exploitation are generally used to describe activities that are essential for organizations in sustaining and ensuring their competitive advantages (Isobe, Makino, and Montgomery 2004 Sidhu, Commandeur, and Volberda 2007). In his seminal paper, March (1991) describes exploitation and exploration as two different forms of learning activities. Exploration strategies are associated with search, discovery, experimentation and development of new knowledge, while exploitation strategies involve activities that seek the refinement and extension of existing knowledge and are associated with convergent thinking (Levinthal and March 1993).

The Resource Based View and the Dynamic capabilities approach are considered as models that explain exploitation and exploration (Yalcinkaya et al. 2007; Lin et al., 2013). In this study, we assume that the RBV provides the appropriate framework to identify the antecedents of exploitation, while the DC theory might be a more adequate approach to establish the 
antecedents of exploration. In turn, the antecedents of exploitation are regarded as first-order resources and the antecedents of exploration as second-order capabilities (Sidhu et al. 2004; Prange \& Verdier, 2011). This is consistent with the arguments that recognize exploitation as a main firm-level internal function and exploration as a domain-level, fundamentally external function (Auh \& Menguc, 2005; Dutta, 2012).

In this manner, exploitation is the process of taking advantage of what exists, allocating the resources to improve the existing products and processes (March 1991). This includes actions to strengthen the firm's internal resources to develop competitive advantages, proposed by the RBV (Barney, 1991; Grant, 1991). The pressure to achieve efficiency makes managers focus on developing those internal capabilities which aggregate value (Mom, van den Bosch et al. 2007; Bierly et al., 2009).

Alternatively, exploration represents the process of trying new ways of doing things, such as searching, variation, risk-taking, experimentation, flexibility and discovery (March 1991). This is associated with the possibilities of development beyond organizational limits and, therefore, involves relationships with the environment in which the firm seeks to absorb new knowledge (Bierly et al.2009) and achieve synergies in the inter-organizational networks (Lavie, Kang \& Rosenkopf, 2011). All this will let the firm adapt, integrate and reconfigure its resources to build higher-order capabilities (Teece et al.1997; Marín-Idárraga et al.,2015). In the context of exploration and exploitation strategies, researchers have started to address the importance of the opportunities and threats that come from the environment (Wang and $\mathrm{Li}$ 2008; Yamakawa, Yang, and Lin 2011). In keeping with this idea, Das (2006) and Hendry and Brown (2006) have argued that, since to explore and to exploit at the same time allows firms to adapt to new requirements over time, they could be conceived of as a dynamic process of strategic renewal. In the same vein, Crossan, Lane, and White (1999) and Fischer et al. (2010) have conceptualized exploration and exploitation strategies as dynamic capabilities, as they have the capacity to formulate a response to a need or an opportunity for change. In addition to being considered dynamic capabilities that allow firms to adapt to their environment over time, exploration and exploitation strategies have been studied under the effect of some dimensions of the firm's environment (Jansen, Van Den Bosch, and Volberda 2006; Yang and Li 2011; Bernal et al., 2018).

\section{Strategic Orientation}

Some researchers consider strategic orientation as dynamic capability that represents the organization's ability to integrate and built internal and external competencies (Zhou et al. 2005), as other authors consider orientation as elements of the organizational culture (Nobel et al. 2002). So, the strategic orientation reflects the beliefs and values that are deeply rooted in the company and define its focus for achieving a competitive advantage, constituting a determining factor for the configuration of the resources required to achieve this goal (ScottKennel \& Giroud, 2015).

In this regard, strategic orientation is related to the decisions that businesses make to achieve superior performance. Strategic orientation is an organization's direction for reaching a suitable behaviour to attain superior performance. (Hult et al., 2005; Yang et al, 2012; AlMohammad, 2010; Langerak et al, 2004; Kumar et al, 2011; Nasution et al, 2011; Lau, 2011; Hao and Song,2016). 


\section{Innovation capability}

Innovation capability, defined as a firm's ability to generate, accept, and implement new ideas, processes, products, or services, is one of the key resources that drive a firm's success in the marketplace (Calantone, Cavusgil, \& Zhao, 2002; Ngo \& O'Cass, 2013; Thornhill, 2006, Sulistyo and Siyamtinah, 2016).

According to Adler and Shenbar (1990), innovative capability is defined as: (1) the capacity of developing new products satisfying market needs; (2) the capacity of applying appropriate process technologies to produce these new products; (3) the capacity of developing and adopting new product and processing technologies to satisfy the future needs; and (4) the capacity of responding to accidental technology activities and unexpected opportunities created by the competitors. A firm's capabilities are important in providing and sustaining its competitive advantage, and in the implementation of the entire strategy. In this sense, recent developments, however, emphasize a need for a more dynamic perspective that addresses innovation in the business model (e.g., Bjorkdahl and Holm, 2013; Chesbrough, 2010; Sanchez and Ricart, 2010; Zott et al., 2011; Massa et al., 2017; Hacklin et al., 2018).

\section{Managerial Capabilities}

According to Ho (2008), a managerial capability refers to an organisation's skills, knowledge and experiences, which are used to handle difficult and complex tasks in management and production (Choi and Shepherd, 2004). Management skills allow for the identification of the basic competences, communication to the employees and the employees accepting these basic competences. Managerial capabilities and their relationship with the firm's performance has been analysed in many studies, finding a positively correlated link (Welter et al., 2013; Ortega 2010; Lorenzo et al., 2018 For managers to perform their managerial tasks adequately, they must possess firm-specific knowledge which is history-dependent or acquired through learning by doing (Barney, 1991). These capabilities enable top management teams to face their environment, improve organizational performance, and maintain and create competitive advantages (Carmeli and Tishler, 2004). The success of the firm will depend on its effectiveness, along with the skills and knowledge of people working in the organization (Pickett, 1998), who establish priorities and belief systems, and guide managers and employees towards the shaping of business resources and competencies (Kor and Mesko, 2013).By Boeker \& Karichalil (2002), they stated that developing managerial capabilities is necessary for growth. Lado, Boyd, and Wright (1992) further argued that organizations by attaining superior managerial capabilities create the capacity: to create vision, formulate strategies, and make them work by communicating to the workforce Adner \& Helfat, 2003; Helfat \& Peteraf, 2003; Ahmed, 2017). Managers must provide a high degree of commitment, clear definition of objectives and adequate financial resources (Pickett, 1998). The relationship between management capabilities and competitive advantage is based on the successful guidance of managers implementing cost reduction, product differentiation or a combination of both (Schuler and Jackson, 1987). This set of managerial capabilities can become a generator of appropriable incomes and a source of maintenance of competitive advantage (Lado and Wilson, 1994). It also helps explain the relationship between strategic decisions and business performance (Helfat and Martin, 
2015) Their prior research indicates that the manager's knowledge and skills are the bases of managerial capabilities. The organizations are required to continue investing on developing the knowledge and skills to attain superior managerial capabilities that can be used by the organizations to improve performance (Mahoney, (1995: 92).

\section{Conceptual framework and hypotheses}

The tested conceptual model in this study is presented in Figure 1.

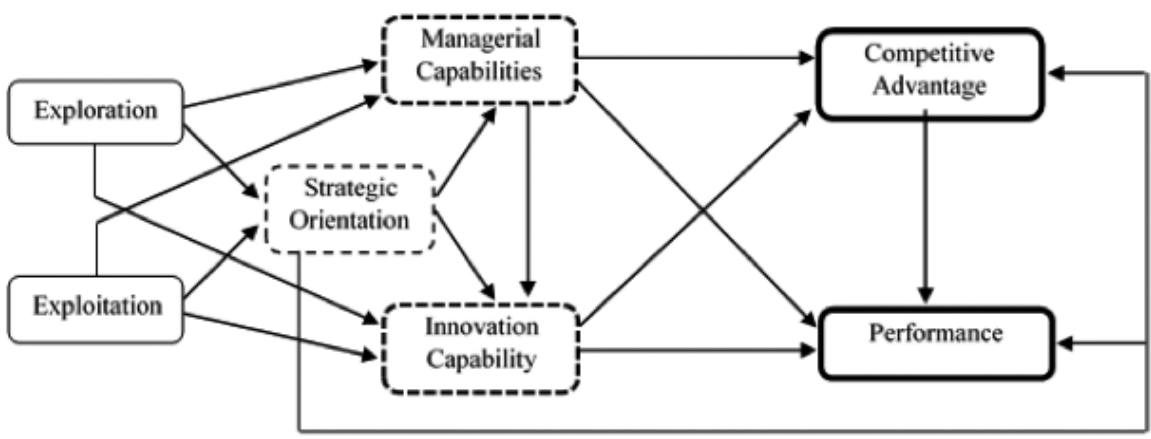

Figure 1.The Conceptual Model

Source: Elaborated by the authors (2014).

\section{The Exploration and Exploitation and Strategic Orientation}

Ambidexterity literature has called for more research on the contextual factors that facilitate ambidexterity, such as culture, values, vision, incentives, and processes (O'Reilly and Tushman, 2011; Markides, 2013). The general agreement established is that achieving organizational ambidexterity by simultaneously pursuing exploration and exploitation is both critical for longterm success and difficult to achieve (Cao et al., 2009). Exploitation is an important means for firms to maximize the benefits of existing resources and capabilities (Yamakawa et al., 2011) As noted by March (1991), exploitation exhibits returns that are positive, proximate, and predictable, while those of exploration are uncertain. Yamakawa et al., (2011) argue that the strategy reflected in a firm's choice of resource allocation can influence the performance consequences of its choice of exploitation or exploration - namely, in terms of strategic orientation.

Consequently, the following hypotheses are proposed:

H1: Exploitation has a positive impact on Strategic orientation

H2: Exploration has a positive impact on Strategic orientation 


\section{Exploration and Exploitation and Innovation Capability}

Compared to exploitation, exploration focuses mainly on trying to create variety, to adapt and hence exploit ever-decreasing windows of opportunity. Organizations engaging in exploratory innovation pursue new knowledge and develop new products and services for emerging markets (Yalcinkaya et al., 2007). As it provides new insight into the design of new features and benefits of a given product, that product is guaranteed to contain new ideas (Cho \& Pucik, 2005). Li, Vanhaverbeke, and Schoenmakers (2008) suggest that exploration and exploitation activities reflect the nature of the innovation process rather than the nature of the outcome. We follow these authors' suggestion and define exploration and exploitation activities from an innovation process perspective. An innovation process may include both exploration and exploitation activities ( $\mathrm{Li}$ et al., 2008). Indeed, prior research suggests that exploration and exploitation activities have different roles in the innovation process and influence different innovation outcomes. Exploration seems to be more important for achieving differentiated and innovative outcomes, while exploitation is more likely to contribute to cost efficiency and profit gains, efficiency in producing the product, and to its quality (Kim \& AtuaheneGima, 2010; Atuahene-Gima, K., \& Murray, 2007; Molina-Castillo et al., 2011; O'Cass et al., 2014). According to Tabeau et al., (2017) exploration activities are characterised by search, experimentation, and investigation, and can result in new knowledge. This new knowledge, generated through exploration activities, is essential to develop radically new solutions (Atuahene-Gima, 2005). Indeed, prior research shows that exploration activities stimulate the development of product characteristics such as differentiation (Kim \& Atuahene-Gima, 2010; O’Cass et al., 2014) and innovativeness (Molina-Castillo et al., 2011).

Each successful organization exploits available resources and explores new knowledge and opportunities. Therefore, ambidexterity increases organization performance and innovation (Cao et al., 2009). Exploitation and exploration have a positive influence on innovation capability (Gibson and Birkinshaw, 2004). The exploration and the exploitation capabilities are precursors to organizational learning and capability building in general and to innovative capabilities (Chung \& Kim, 2002; Lisboa et al., 2012).

Consequently, the following hypotheses are proposed:

H3: Exploration has a positive impact on innovation capability

H4: Exploitation has a positive impact on innovation capability

\section{Exploration and Exploitation and Managerial Capability}

Adner and Helfat (2003) suggest that the characteristics of a firm's top management team are a major contributor to the development of managerial capabilities that ensure sustained competitive advantage. Ambidextrous managers must manage contradictions and conflicting goals (Smith and Tushman, 2005), engage in paradoxical thinking (Gibson and Birkinshaw 2004) and fulfil multiple roles (Lane and Floyd, 2000). When managers engage in innovation-related activities, they typically rely on two strategic orientations in organizational learning, namely exploration and exploitation (Levinthal \& March 1993; March 1991). 
With an exploration orientation, managers actively seek to increase variations in managerial practice, foster the search for new ideas/technologies, encourage risk taking, and discover new opportunities (March 1991). Exploitation orientation, on the other hand, tends to allow managers to discover opportunities using the available resources and focuses more on the innovation implementation process (Rosing, Frese, \& Bausch, 2011; Wang and Dass, 2017). Mom (2007) and Raisch (2009) found that the more a manager acquires the higher the levels of exploration and exploitation activities this manager may undertake. O'Reilly and Tushman (2008) argue that ambidexterity can only become a dynamic capability if managerial capabilities repeatedly and intentionally orchestrates firm resources. Exploitation is focused on delivering expected outcomes within the organization by using a firm's current core capabilities (March 1991; Shane \& Venkataraman, 2000). Activities relating to exploitation often include or have the goal(s) of improving quality and efficiency and fostering existing knowledge, managerial skills, technologies, and capabilities in the organization (Benner \& Tushman, 2002; Lavie, Stettner, \& Tushman, 2010). The exploration often include searching, risk-taking, discovery, experimentation, prototyping, and flexibility (March 1991). The focus of such activities is on the ability to reorient organizational competencies toward new opportunities as a source of competitive advantage (Shane \& Venkataraman, 2000). Exploration entails a shift away from an organization's current knowledge base and skills, directed at new opportunities, technical and managerial skills, market expertise, and/or external relationships (Lavie \& Rosenkopf, 2006; Smith \& Tushman, 2005). While exploration and exploitation could be seen as opposing activities along a continuum (Lavie et al., 2010), both are important actions that affect firm performance (e.g., Gupta, Smith, \& Shalley, 2006) impacting on the firm's environment (e.g., munificence and dynamism; Jansen, Van den Bosch, \& Volberda, 2005) and organizational resources (Lavie et al., 2010; March, 1991) or managerial capabilities (Helfat \& Peteraf, 2009; Goel \& Jones; 2016).

Consequently, the following hypotheses are proposed:

H5: Exploitation has a positive impact on managerial capabilities

H6: Exploration has a positive impact on managerial capabilities

\section{Managerial Capabilities and Innovation Capability}

Hooley et al. (2005) proposes managerial capability as an antecedent of innovation capability. They argue that superior management capabilities, through integration and teamwork, will enhance innovation. Innovation combines not just new idea creation but also systematic and structured management processes or steps.

Cooper (2001) "stage-gate" steps are a special case of the process of managing innovation. Cobbenhagen (2000) gives evidence of the importance of management capabilities in the context of SMEs. In total, the well-documented role of management processes for innovation suggests that management capabilities are likely to influence innovation success. Managerial capabilities refer to the extent to which a firm's top managers have favourable attitudes toward innovation and are willing to take risks to invest resources in innovation activities (Rodríguez, Pérez, \& Gutiérrez, 2008). Accordingly, managers are supportive of innovation activities (Lloréns Montes, Ruiz Moreno, \& Miguel Molina Fernández, 2004). 
According to Kor and Mesko (2013) managerial capabilities contribute to establish a dominant logic in the firm that takes concrete form in routines, procedures, and capabilities that influence implementation of strategies and innovation capability (e.g., Barbero et al., 2011; Carmeli and Tishler, 2004; Kearney et al., 2014; Sirmon and Hitt, 2009; Ruiz-Jiménez and Fuentes- Fuentes. 2016). Motwani et al. (1999) and Merrilees et al., (2011) give evidence of the importance of management capabilities in the context of SMEs. In total, the well-documented role of management for innovation suggests that management capabilities are likely to influence innovation success.

Consequently, the following hypothesis is proposed:

H7: Managerial capabilities positively impacts on innovation capability

\section{Strategic Orientation and Innovation Capability}

The strategic orientation supports risk taking and enhances the possibility of designing and developing completely new and innovative products (Olson e al. 2005). Strategic orientation constitutes a determining factor in ensuring that innovative capabilities produce positive results for a company (Ozkaya et al., 2015). The behaviour required to satisfy the needs and expectations of customers influences the innovative capabilities that can help to enhance business performance, particularly in environments in which changes are rapid and discontinuous (Zhou et al., 2005). Regarding innovation, a strategic orientation influences and directs the development of innovative activities by a company to make its relationship with its customers more dynamic (Zhou et al., 2005). Strategic orientation was first introduced by Kohli and Jaworski (1990) and continued through different studies by Noble et al. (2002). Strategic orientation is the philosophy of firms which demonstrates their efforts to gain higher performance and displays how a job ought to be done with a set of values and beliefs (Gatignon and Xuereb, 1997; Izadi and Ahmadian, 2018). Tutar, Nart and Bingol (2015) performed a research has been developed under the assumption that strategic orientation dimensions have positive effects on innovation capability. Supported by the literature, we posit the following hypothesis:

H8: Strategic Orientation has a positive impact on Innovation Capability

\section{The Strategic Orientation and Managerial Capabilities}

The relationship between strategic types and key management characteristics has been examined in previous studies. Generally, strategic orientation differs about managerial factors and basic competences (Conant et al.1990). The strategic orientation reflects the beliefs and values that are deeply rooted in the company and define its focus for achieving a competitive advantage, constituting a determining factor for the configuration of the resources required to achieve this goal (Scott-Kennel \& Giroud, 2015). According to, Sinkovics and Roath (2004) and Hitt (2000) the strategic orientation reflects managers' perceptions of the environment and their reactions to environmental conditions. Strategic orientation involves the guiding 
principles that shape the managerial decision-making of a company, the configuration of its resources and its interaction with the market in which it operates (Chen et al., 2014; Song \& Parry, 2009). The willingness of companies to adopt innovation and make it a central activity appears to be linked to strategic orientation, which influences the managerial capabilities when it comes to determining directives and decision-making (Chang et al., 2014; Atuahene-Gima, 1995). Based on the literature, we posit the following hypothesis:

H9: Strategic Orientation have a positive impact on managerial capabilities

\section{Strategic Orientation and Competitive Advantage}

Business strategy has been characterized as the way a firm decides to compete, which encompasses the pursuit, achievement, and maintenance of competitive advantage in SMEs (Varadarajan \& Clark, 1994). Given its position as a nucleus issue in organizational decision making, it is not surprising that the concept of strategic orientation has beenassociated to performance outcomes. Indeed, it is a key postulate to which many management researchers devote attention, because without doubt "the notion that superior performance requires a business to gain and hold an advantage over competitors is central to contemporary strategic thinking" (Day and Wensley, 1988, p. 1).

Strategic orientation reflects the firm's philosophy of how to conduct business through a deeply rooted set of values and beliefs that guides the firm's attempt to achieve superior performance (Gatignon \& Xuereb 1997). Also, strategic orientation is firm specific, culturebased, and complex capabilities that can be lead to competitive advantage (Zhou et al., 2005). The strategic orientation reflects the beliefs and values that are deeply rooted in the company and define its focus for achieving a competitive advantage, constituting a determining factor for the configuration of the resources required to achieve this goal (Scott-Kennel \& Giroud, 2015; Gatignon \& Xuereb, 1997; Day, 1994), Since strategic orientations are valuable, scarce, imperfectly tradable and difficult to imitate resources, they can turn into a significant source of competitive advantage (Hult y Ketchen, 2001). Strategic orientation might help new ventures adapt to the fast-changing market as well as obtain and maintain competitive advantage (Jiao et al. 2013; Teece 2007; Winter 2003; Zott 2003) by building possible dynamic capabilities (Zhou and $\mathrm{Li}$ 2010). Consequently, the following hypothesis is proposed:

H10: Strategic Orientation has a positive impact on competitive advantage

\section{The Innovation Capabilities, Competitive Advantage and Performance}

Innovation is one of the key instruments to increase market share and to give the company a competitive advantage (Gunday et al., 2011), having a positive impact on the performance of companies, producing a better position in the market resulting in competitive advantage and superior performance (Gomes and Wojahn, 2017). Innovation capability is considered as the valuable assets for the firms to provide and sustain competitive advantage a (Lawson \& Samson, 2001). The capability of innovation facilitates firms to introduce new product quickly and adopt new systems rather it is important to factor for feeding the ongoing competition (Rajapathirana and Hui, 2018). 
Marketing and innovation are necessary for firms to gain competitive and vantages (Song et al., 2005). Innovation capability can help companies to gain an "isolation mechanism" that protects the advantages and benefits they have (Lavie, 2006). Successful innovation can make it more difficult for external imitation and allows the company to maintain its competitive advantage better (Morales et al., 2007). For that reason, innovation can affect competitive advantages and performance (Wingwon, 2012). Consequently, the following hypotheses are proposed:

H11: Innovation capability positively impacts on competitive advantage

H12: Innovation capability positively impacts on performance

\section{The Managerial capabilities and Competitive Advantage}

Managerial capability is based on the dynamic capability view - an extension of RBV (Teece, 2007). Organizations require dynamic capabilities to effectively adapt to the changing market conditions and create value. These capabilities help organizations in creating and modifying existing operating routines, sensing and seizing entrepreneurial opportunities that in turn increase organizational effectiveness and competitive advantage. Managerial capabilities refer to the capabilities with which managers construct, integrate, and reconfigure the organization's resources and competences (Adner and Helfat, 2003). These capabilities enable top management teams to face their environment, improve organizational performance, and maintain and create competitive advantages (Carmeli and Tishler, 2004; Ruiz-Jiménez and Fuentes -Fuentes; 2016).

Similarly, we contend that higher managerial capability should enable providers to better manage i.e., bundle and leverage various firm-level resources and capabilities through creation of valuable synergy resulting in performance enhancement (Sirmon \& Hitt, 2009).

Consequently, the following hypothesis is proposed:

H13: Managerial capabilities positively impacts on competitive advantage

\section{The Competitive Advantage and Performance}

To gain competitive advantage by attaining a certain level of organizational performance is the primary condition for the successful organization on long-term (Striteska \& Jelinkova, 2015).

Studies have found that there is a significant relationship between competitive advantage and the performance of organizations, when sales-based performance was measured by the level of sales revenue, profitability, return on investments, productivity, product added value, market share and product growth (Wang and Lo, 2003; Rose et al., 2010;Pearson et al., 2015; Nilssen et al.,2015) Consequently, the following hypothesis is proposed:

H14: Competitive advantage has a positive impact on Performance 


\section{Methodology}

Sample and Data Collection

To test the proposed investigation model and the research hypotheses, data was collected via a structured questionnaire. A total of 387 questionnaires were obtained from Portuguese SMEs. Furthermore, a key informant in each company was contacted to complete the questionnaire.

The respondents were scattered throughout Portugal with no sector being specially represented.

Twenty-eight percent were from companies with less than 20 employees, $42 \%$ from companies with between 21 and 50 employees, $8 \%$ from companies with between 51 and 100 employees, and $22 \%$ with more than 100 employees until 200 employees.

Forty three percent of the companies were share companies, $42 \%$ private limited companies, and $15 \%$ single shareholder companies. In terms of lifespan, $25 \%$ of the firms were less than 10 years old, $65 \%$ had between 10 and 20 years, $7 \%$ between 21 and 50 years, and 3\% more than 51 years.

\section{Measures}

To operationalize the variables, the researchers conducted a literature review and adapted scales used in existing studies, changing and adapting the vocabulary so that the scales were more perceptible for respondents.

\section{Strategic Orientation}

Business unit strategic orientation was measured using a 22-item scale developed by Dess \& Davis (1984) and modified by Doty, Glick \& Huber (1993). Respondents rated their major business unit on items designed to measure the extent to which they were developing costbased and differentiation-based strategies (Porter 1980). Items like "Provide unique products or services?" or "Be the lowest cost provider in your industry?"

\section{Innovation Capability}

The survey instrument asked respondents to indicate their perceptions about the items pertaining to brand capability, innovation capability, firm characteristics, marketing performance and financial performance. Most of the scales are drawn from or adapted from Hooley, (2005) and suggested by Merrilees, (2011). Items like "Better at developing new ideas to help customers".

\section{Dynamic Capabilities - Exploration and Exploitation}

Dynamic Capabilities - exploration and exploitation - were measured using two dimensions, with five items each, competence exploration and competence exploitation, suggested by Atuahene-Gima (2005). Items like "Acquired manufacturing technologies and skills entirely new to the firm" were used as well as "Upgraded current knowledge and skills for familiar products and technologies". 


\section{Competitive Advantage}

Competitive advantage was measured by Vokurka et al., 2002; Thatte et.al. 2009, suggested cost, quality, dependability and speed of delivery as some of the critical competitive priorities. Items like "Offer prices as low as or lower than our competitors" were used

\section{Performance}

Performance was measured based on Morgan et al. (2003). Two dimensions of the construct were involved, each having four items that showed on the exploratory and then on the confirmatory factor analysis, to load on one simple factor. The efficiency with which the firm generates cash flows and profits might also be an important accounting indicator of financial performance. This is typically captured in "Return on ..." or "re-investment" type measures that express profit and cash flow as a ratio of some measure of the capital employed or sales revenue of the firm as well as the growth on sales and on market share.

\section{The Model}

All the items were measured on a seven-point Likert scale (1=strongly disagree to $7=$ strongly agree). Confirmatory factor analysis was used to assess the psychometric properties of the scales and the measurement model fit, using AMOS 21. The final model shows a good fit (IFI=0.917; TLI=0.909; CFI=0.917; RMSEA=0.061; CMIN/DF=2.420).

Composite reliability (CR) and the average variance extracted (AVE) were computed. All the scales showed values above 0.8 on CR and above 0.7 on AVE, which are in line with the recommendations (Hair et al. 2006). Discriminant validity is evidenced by the fact that all correlations between the constructs are significantly smaller than 1 and the squared correlations calculated for each pair of constructs is always smaller than the variance extracted for correspondent constructs (Shiu et al., 2011), thereby confirming the discriminant validity.

Table 1

Square Correlations, Cronbach's Alpha Composite reliability and Variance extracted

\begin{tabular}{lllllllll}
\hline Construct & X1 & X2 & X3 & X4 & X5 & X6 & CR & AVE \\
\hline Exploitation & 0.94 & & & & & & 0.89 & 0.72 \\
Exploration & 0.63 & 0.89 & & & & & 0.92 & 0.78 \\
Strategic Orientation & 0.60 & 0.50 & 0.88 & & & & 0.95 & 0.83 \\
Innovation Capability & 0.42 & 0.43 & 0.48 & 0.88 & & & 0.91 & 0.76 \\
Competitive Advantage & 0.55 & 0.37 & 0.63 & 0.49 & 0.90 & & 0.91 & 0.76 \\
Performance & 0.37 & 0.21 & 0.55 & 0.33 & 0.94 & 0.90 & 0.93 & 0.76 \\
\hline
\end{tabular}

Source: Elaborated by the authors (2014).

Diagonal in bold - Cronbach’s Alpha; CR - Composite Reliability; AVE - Average Variance Extracted 


\section{Common Method Bias}

Based on Podsakoff suggestions (1986), a Harman's single factor test and a common latent factor (CLF) analysis were performed to capture the common variance among all observed variables in the model. The Harman's test showed that any factor could explain more than $23 \%$ of the variance and there were 11 factors with eigenvalues greater than 1, explaining $73 \%$ of the total variance.

A confirmatory factor analysis was conducted restricting all items of the model to load on a common single factor (Podsakoff, 2003). The resulting fit indices show the model did not provide a good adjustment for the data: $\mathrm{CMIN} / \mathrm{DF}=2$. 02 ; $\mathrm{IFI}=0.68 ; \mathrm{TLI}=0.673 ; \mathrm{CFI}=0.680$, which means that common method bias is not a problem for this data set.

\section{Results and discussion}

Amos 21.0 was used to perform CFA and SEM to test the proposed hypotheses. The final model shows a good fit with $\mathrm{IFI}=0.917$, TLI=0.909, CFI=0.917, RMSEA=0.061 e CMIN/ $\mathrm{DF}=2.420$ (Anderson and Gerbing, 1988).

Table 2

Estimation of the Structural Model (Global $-\mathrm{n}=387$ )

\begin{tabular}{|c|c|c|c|c|c|c|c|}
\hline Hypothesis & Relationship & & & SRW & C.R. & $\mathrm{P}$ & Sup. / Not S \\
\hline $\mathrm{H} 1$ & Strategic Orientation & $\leftarrow$ & Exploitation & .464 & 6.633 & $* * *$ & Supported \\
\hline $\mathrm{H} 2$ & Strategic Orientation & $\leftarrow$ & Exploration & .248 & 3.810 & $* * *$ & Supported \\
\hline $\mathrm{H} 3$ & Innovation Capability & $\leftarrow$ & Exploitation & .100 & 1.481 & $* * *$ & Supported \\
\hline $\mathrm{H} 4$ & Innovation Capability & $\leftarrow$ & Exploration & .079 & 1.363 & $* * *$ & Supported \\
\hline H5 & Managerial Capabilities & $\leftarrow$ & Exploration & .123 & 1.876 & $* * *$ & Supported \\
\hline H6 & Managerial Capabilities & $\leftarrow$ & Exploitation & -.055 & -.746 & .225 & Not Supported \\
\hline $\mathrm{H} 7$ & Innovation Capability & $\leftarrow$ & Managerial Capabilities & .504 & 5.852 & $* * *$ & Supported \\
\hline $\mathrm{H} 8$ & Innovation Capability & $\leftarrow$ & Strategic Orientation & .250 & 2.491 & $* * *$ & Supported \\
\hline H9 & Managerial Capabilities & $\leftarrow$ & Strategic Orientation & .593 & 5.911 & $* * *$ & Supported \\
\hline H10 & Competitive Advantage & $\leftarrow$ & Strategic Orientation & .704 & 6.240 & $* * *$ & Supported \\
\hline H11 & Competitive Advantage & $\leftarrow$ & Innovation Capability & -.088 & -.786 & .216 & Not Supported \\
\hline $\mathrm{H} 12$ & Performance & $\leftarrow$ & Innovation Capability & .582 & 7.315 & $* * *$ & Supported \\
\hline H13 & Competitive Advantage & $\leftarrow$ & Managerial Capabilities & -.042 & -.432 & .333 & Not Supported \\
\hline H14 & Performance & $\leftarrow$ & Competitive Advantage & .289 & 5.009 & $* * *$ & Supported \\
\hline
\end{tabular}

Source: Elaborated by the authors (2014). 
The results of the estimation of the structural model in Table 2 confirm H1, as exploitation has a positive impact on strategic orientation $(0.464 ; P \leq 0.01)$ and $\mathrm{H} 2,(0.248 ; P \leq 0.01)$, as exploration has a positive impact on strategic orientation. Thereby, the exploitation and exploration have a significantly influence on strategic orientation. These results are in line with prior literature that exploitation and exploration are fundamentally different logics that create tension because they compete for firms' scarce resources and strategic focus (Nielsen, 2010).

There is a positive relationship between exploitation and exploration and innovation capability, respectively, $(0.100 ; P \leq 0.01)$ and $(0.079 ; P \leq 0.01)$. Thus, supporting $\mathrm{H} 3$ and H4. These results are according to the literature in which exploration and innovation capabilities help units to encounter rapid obsolescence of products and services (Ahuja/Lampert (2002)).

$\mathrm{H} 5$ is confirmed, as exploration has a positive impact on managerial capability, $(0.123$; $P \leq 0.01)$. According to studies of organizational learning the essence of exploration activities is creating variety in experience (Holmqvist, 2004; McGrath, 2001) which is associated with broadening a manager's existing knowledge base (Cf. Katila and Ahuja, 2002; Sidhu et al., 2004).

The exploitation doesn't seem to have a significant impact on managerial capabilities. Consequently, not supporting H6 $(-0.055 ; P \geq 0.05)$. This result is not in line with prior investigation, confirming that the essence of exploitation activities is creating reliability in experience (Levinthal and March 1993) associated with deepening the manager's existing knowledge base (Cf. Katila and Ahuja, 2002).

However, managerial capabilities have a positive impact on innovation capability $(0.504$; $P \leq 0.01$ ). Consequently, supported H7. This result is in line with study of how management capabilities affect innovation capability and performance in SMEs might be conditioned by greater administrative flexibility and a strong participation of the top management in the firm's processes and activities (Escribá-Esteve et al., 2009).

$\mathrm{H} 8$ is confirmed, $(0.100 ; P \leq 0.01)$, as there is a positive relationship between strategic orientation and innovation capability. Consequently, strategic orientation has a significantly influence on innovation capability. In fact, strategic orientation corresponds to the guiding principles that shape managerial decision-making in a company, the configuration of its resources and its interaction with the market in question (Chen et al., 2014).

Strategic orientation has a positive impact on managerial capabilities. Thus, H9 is supported $(0.593 ; P \leq 0.01)$. This relationship is in line with prior investigations. The strategy-formulation perspective is widely used to study the role of strategic orientation (Homburg et al., 2002). Its basic proposition is that there is no universally beneficial strategic choice, and companies need to examine certain sets of organizational and environmental conditions to develop their strategies

There is a positive relationship between strategic orientation and competitive advantage. Consequently, supporting $\mathrm{H} 10(0.704 ; P \leq 0.01)$ in terms by literature that market-oriented companies possess inherent characteristics that drive their competitive capabilities to build enhanced performance (Narver and Slater, 1990), and that such strategic orientation provides a superior ability to compete (Zhou et al., 2005).

On the other hand, innovation capability doesn't seem to have a significant impact on competitive advantage, consequently, not supporting H11 (-0.088; $P \geq 0.05)$. This result is not in line with prior investigations, considering innovation capability a special asset of a firm.

H12 is supported, as innovation capability has a positive impact on Performance, $(0.582$; 
$P \leq 0.01)$. Thus, the innovation capability has a significantly influence on performance. Mone et al. (1998) and Cooper (2000) argue that innovation capability is the most important determinant of firm performance. The diffusion of innovations literature suggests that firms must be innovative to gain a competitive edge to survive (Li \& Calantone, 1995; 2002).

However, managerial capabilities don't seem to have a significant impact on competitive advantage, consequently, not supporting H13, (-0.042; $P \geq 0.05)$. This result is in contradiction with the result of previous studies that argue that organization's management capabilities are crucial to achieving congruence among its competences and the changing conditions of its environment (Kor and Mesko, 2013).

Obviously, H14 is supported. Thereby, competitive advantage has the positive and strong impact on performance $(0.289 ; P \leq 0.01)$. In fact, research in the last decade obtains empirical evidence of the relationship between management capabilities, strategy, and performance (Adner and Helfat, 2003; Kearney et al., 2014).

\section{Implications}

The nature of the relationship between dynamic capabilities and competitiveness and performance it is not clear, (Ferreira \& Coelho, 2017), namely, whether the relationship is direct or indirect. At the same time, most of the investigation in this field has been produced in developed countries and little is known about how dynamic capabilities operate in transition economies Accordingly, this investigation brings three main contributions: first, investigating the relationship between dynamic capabilities and organizational competitiveness and performance based on companies operating in Portugal, a transition economy; second, introducing strategic orientation, innovation and managerial capabilities as mediators in this relationship; third, establishing a chain of effects that highlights how the effects of dynamic capabilities are transferred to competitiveness and performance.

At the same time, this investigation gives important clues on how companies and their managers may take advantage of their dynamic capabilities. In addition to the intrinsic value and importance of dynamic capabilities, specific capabilities like innovative and managerial capabilities, associated with a strategic orientation, may help companies take a better advantage of their resources and boost performance and competitiveness (Cheng \& Chen, 2013; Sheng, 2018). Investments on new resources and the reinforcement of dynamic capabilities are an important step but only if companies develop their capabilities to better operate these resources and transform them in effective competitiveness.

\section{Conclusions}

The main goals of this research were to evaluate the impacts of dynamic capabilities (exploitation and exploitation) on competitive advantage and performance, mediated by strategic orientation, managerial and innovation capabilities. The moderating role of ambidexterity was tested to provide a specific context where these relationships could take place.

The mediating effects of strategic orientation, innovation and managerial capabilities were used to get a better understanding of the links between dynamic capabilities and performance 
and competitiveness, and the effects from dynamic capabilities on them. The character of dynamic capabilities is rather cultural (Chen \& Lee, 2009), and their impacts on performance normally are indirect. The direct effects that were always revealed as being insignificant were removed from the final model.

The results show that dynamic capabilities have an indirect effect on performance and competitiveness, via strategic orientation, innovation and managerial capabilities. These last capabilities act like an instrument from dynamic capabilities to help companies be more competitive and perform better. Strategic orientation exerts a strong and significant influence both on competitiveness and performance, while managerial capabilities may reinforce the effects of dynamic capabilities on innovation capabilities.

This paper makes two contributions to the marketing and innovation management literature. Firstly, this paper provides new empirical evidence of the positive effect of ambidexterity in the context of strategic orientation, marketing and innovation capabilities. While the beneficial effect of balancing exploration and exploitation has been hypothesized in the literature, there have been few studies providing moderating empirical evidence (Andriopoulos, C., Lewis, M.W., 2010: Raisch, S., Zimmermann, A., 2017).This paper considers two somewhat different conceptual interpretations of ambidexterity and has found empirical support for both interpretations. Thus, although our study did not explicitly address the issue of what organizational design principles are appropriate for ambidexterity, our findings lend support to the case for pursuing ambidextrous organization designs. As for our findings are limited to the specific context of marketing and innovation, we suggest that the methodological approach of this paper may be adapted to test the ambidexterity hypothesis in other management research domains as well.

Secondly, this paper adds to a wider understanding of innovation management by extending the exploration versus exploitation construct to characterize how firms prioritize their resources for marketing and innovation (Koryak et al., 2018). As the exploration versus exploitation construct has generated significant insights in other domains of management research, we believe that our operationalization of marketing and innovation strategies grounded on the exploration versus exploitation distinction may have several important implications for innovation management as well.

\section{Limitations and future research}

This study has some methodological limitations affecting its potential contributions. As a cross-sectional study that captures one image in time, its ability to identify strict causality between variables is limited. Because capabilities and creativity-innovation co-evolve in a dynamic process, the ideal study might be longitudinal. Furthermore, the results are based on data collected from a key respondent, rather than broader actual data.

As recommendations for future work, the model could be tested introducing variables like entrepreneurial and market orientation, both as mediators or moderators. Innovation and new product success are relevant outcomes which could be tested. 


\section{References}

Adler, P.S., Shenbar, A., (1990). Adapting your technological base: the organizational challenge. Sloan Management Review, 25, 25-37.

Adner, R.; \& Helfat, C.E. (2003). Corporate effects of dynamic managerial capabilities. Strategic Management Journal, 24,1011-1025. https://doi.org/10.1002/smj.331

Ahuja, G., \& Lampert, C.M. (2001). Entrepreneurship in the large corporation: A longitudinal study of how established firms create breakthrough inventions. Strategic Management Journal, 22, 521-543. https://doi.org/10.1002/ smj.176

Ahmed, K.A. (2017). The Influence of Development on Managerial Capabilities and Performance: Empirical Evidence from Pakistan, Journal of Southeast Asian Research, 20, 1-12 https://doi.org/10.5171/2017.164526

Andriopoulos, C., Lewis, M.W., (2010). Managing innovation paradoxes: ambidexterity lessons from leading product design companies. Long Range Planning. 43(1),104-122. https://doi.org/10.1016/j.lrp.2009.08.003

Al-Mohammad, S. (2010). Market orientation, new product development and new product performance: a model and test. Jordan Journal of Business and Administration 6, 555-580.

Atuahene-Gima, K. (1995). The influence of new product factors on export propensity and performance: an empirical analysis. Journal of International Marketing, 3 (2),11-28.

Atuahene-Gima, K., \& Murray, J. Y. (2007). Exploratory and exploitative learning in new product development: A social capital perspective on new technology ventures in China. Journal of International Marketing, 15 (2),1-29 https://doi.org/10.1509/jimk.15.2.1

Atuahene-Gima, K. (2005). Resolving the capability - rigidity paradox in new product innovation. Journal of Marketing, 69(4),61-83. https://doi.org/10.1509/jmkg.2005.69.4.61

Auh, S. and Menguc, B. (2005). Balancing Exploration and Exploitation: The Moderating Role of Competitive Intensity. Journal of Business Research 58,1652-61. https://doi.org/10.1016/j.jbusres.2004.11.007

Barbero, J.L., Casillas, J.C., Feldman, H.D., (2011). Managerial capabilities and paths to growth as determinants of high-growth small and medium-sized enterprises. Int. Small Bus. J. 29, p671-694. https://doi. org/10.1177/0266242610378287

Barney, J. (1991). Firm Resources and Sustained Competitive Advantage. Journal of Management, 17, 99-120. https:// doi.org/10.1177/014920639101700108

Barreto, I. (2010). Dynamic capabilities: a review of past research and an agenda for the future. Journal of Management, 36(1), 256-280. https://doi.org/10.1177/0149206309350776

Benner, M. J., \& Tushman, M. (2002). Process management and technological innovation: A longitudinal study of the photography and paint industries. Administrative Science Quarterly 47, 676-707. https://doi.org/10.2307/3094913

Bernal, P., Maicasb, J P. \& Vargas, P. (2019). Exploration, exploitation and innovation performance: disentangling the evolution of industry. Industry and Innovation, 26(3), 295-320, DOI: 10.1080/13662716.2018.1465813

Bierly, P.E., Damanpour, F. and Santoro, M.D. (2009) The Application of External Knowledge: Organizational Conditions for Exploration and Exploitation. Journal of Management Studies, 46, 481-509. https://doi.org/10.1111/ j.1467-6486.2009.00829.x

Bjorkdahl \& J., Holm, M., (2013). Business model innovation: the challenges ahead. International Journal of Product Development 18(3/4),213 -225.

Boeker, Warren and R. Karichalil (2002). Entrepreneurial Transitions: Factors Influencing Founder Departure. Academy of Management Journal, 45 (4), 818-826. https://doi.org/10.5465/3069314

Braganza, A., Brooks, L., Nepelski, D., Ali, M.\& Moro, R. (2017). Resource management in big data initiatives: Processes and dynamic capabilities. Journal of Business Research 70,328-337. https://doi.org/10.1016/j.jbusres.2016.08.006

Calantone, R., Cavusgil, S., \& Zhao, Y. (2002). Learning orientation, firm innovation capability and firm performance. Industrial Marketing Management 31, 515-524. https://doi.org/10.1016/s0019-8501(01)00203-6

Cao, Q., Gedajlovic, E.,\& Zhang, H. (2009). Unpacking organizational ambidexterity: dimensions, contingencies, and synergistic effects. Organization Science, 20(4), 781-796. https://doi.org/10.1287/orsc.1090.0426 
Carmeli, A., Tishler, A., (2004). The relationships between intangible organizational elements and organizational performance. Strategy Management Journal. 25(13), 1257-1278 https://doi.org/10.1002/smj.428

Cepeda, G., \& Vera, D. (2007). Dynamic capabilities and operational capabilities: a knowledge management perspective. Journal of Business Research, 60(5), 426-437. https://doi.org/10.1016/j.jbusres.2007.01.013

Chang, W., Franke, G. R., Butler, T. D., Musgrove, C. F., \& Ellinger, A. E. (2014). Differential mediating effects of radical and incremental innovation on market orientation: performance relationship: a meta-analysis. Journal of Marketing Theory and Practice, 22(3),235-249. https://doi.org/10.2753/mtp1069-6679220301

Chen, X., Chen, A. X., \& Zhou, K. Z. (2014). Strategic orientation, foreign parent control, and differentiation capability building of international joint ventures in an emerging market. Journal of International Marketing, 22(3),30-49. https://doi.org/10.1509/jim.13.0013

Chen, H.-H., \& Lee, P.-Y. (2009). The Driving Drivers of Dynamic Competitive Capabilities: A New Perspective on Competition. European Business Review, 21(1),78-91. https://doi.org/10.1108/09555340910925193

Cheng, C. C., \& Chen, J.-S. (2013). Breakthrough innovation: The roles of dynamic innovation capabilities and open innovation activities. Journal of Business \& Industrial Marketing, 28(5) 444-454 https://doi. org/10.1108/08858621311330281

Chesbrough, H., (2010). Business model innovation: opportunities and barriers. Long Range Planning. 43(2/3), 354363 https://doi.org/10.1016/j.lrp.2009.07.010

Cho, H.J., \& Pucik, V. (2005). Relationship between innovativeness, quality, growth, profitability, and market value. Strategic Management Journal, 26(6), 555-575. https://doi.org/10.1002/smj.461

Choi, Y. R., \& Shepherd, D. A. (2004). Entrepreneurs' decisions to exploit opportunities. Journal of Management, 30(3), 377-395. https://doi.org/10.1016/j.jm.2003.04.002

Chung K \& Kim D. A (2002). Study on the relationship between organizational commitment, market orientation and organizational learning. Journal Global Acad Mark Sci. 10, 139-64.

Cobbenhagen, J. (2000). Successful innovation: towards a new theory for the management of SMEs. Cheltenham: Edward Elgar.

Conant, J. S., Mokwa, M. P., \& Varadarajan, P. R. (1990). Strategic types, distinctive marketing competencies and organizational performance: a multiple measures $\square$ based study. Strategic Management Journal, 11(5), 365-383. https://doi.org/10.1002/smj.4250110504

Cooper, R. G. (2001). Winning at new products: accelerating the process from idea to launch. Cambridge, MA: Perseus Books.

Cooper, A. C., Markman, G. D. and Niss, G. (2000). The Evolution of the Field of Entrepreneurship, In G. D. Meyer and K. A. Heppard (Eds.), Entrepreneurship as strategy, Sage Publications, Thousand Oaks, CA, pp. 115-33).

Crossan, M. M., H. W. Lane, \& R. E. White. (1999). An Organizational Learning Framework: From Intuition to Institution. Academy of Management Review 24(3),522-537. https://doi.org/10.5465/amr.1999.2202135

Danneels, E., (2010). Trying to become a different type of company: dynamic capability at smith corona. Strategic Management Journal 32,1-31. https://doi.org/10.1002/smj.863

Das, T. K. (2006). Strategic Alliance Temporalities and Partner Opportunism. British Journal of Management. 17,1-22. https://doi.org/10.1111/j.1467-8551.2006.00482.x

Day, George S. (1994). The Capabilities of Market-Driven Organizations, Journal of Marketing, 58, 37- 52. https:// doi.org/10.2307/1251915

Day, G.S., \& Wensley, R. (1988). Assessing advantage: a framework for diagnosing competitive superiority. Journal of Marketing 52,1-20. https://doi.org/10.2307/1251261

Dess, G.G. \& Davis, P.S. (1984). Porter's (1980) generic strategies as determinants of strategic group membership and organisational performance, Academy of Management Journal 27, 467-88. https://doi.org/10.5465/256040

Doty, D.H., Glick, W.H. \& Huber, G.P. (1993) Fit, equifinality, and organisational effectiveness: A test of two configurational theories, Academy of Management Journal, 30, 1196-250 https://doi.org/10.5465/256810

Drnevich, P. L., \& Kriauciunas, A. P. (2011). Clarifying the conditions and limits of the contributions of ordinary and dynamic capabilities to relative firm performance. Strategic Management Journal 32, 254-279. https://doi. org/10.1002/smj.882 
Dutta, S.K. (2012). Dynamic Capabilities: Fostering Ambidexterity. Journal of Indian Management 9, 81-91.

Eisenhardt, K. M., \& Martin, J. A. (2000). Dynamic capabilities: What are they? Strategic Management Journal, 21(10-11), 1105-1121.

Escriba-Esteve, A., Sanchez-Peinado, L., and Sanchez-Peinado, E. (2009). The influence of top management teams in the strategic orientation and performance of small and medium-sized enterprises. British Journal of Management, 20 (4), 581-597. https://doi.org/10.1111/j.1467-8551.2008.00606.x

Fainshmidt, S., Pezeshkan, A., Lance Frazier, M., Nair, A., \& Markowski, E. (2016). Dynamic capabilities and organizational performance: A meta-analytic evaluation and extension. Journal of Management Studies 53(8), 13481380. https://doi.org/10.1111/joms.12213

Ferreira, J \& Coelho, C. (2017). Dynamic capabilities, managerial and marketing capabilities and their impact on the competitive advantage and firm performance, Int. J. Entrepreneurship and Small Business, 30(4),629-648. https:// doi.org/10.1504/ijesb.2017.10003389

Fischer, T., H. Gebauer, M. Gregory, G. Ren, and E. Fleisch. (2010). Exploitation or Exploration in Service Business Development? Insights from a Dynamic Capabilities Perspective. Journal of Service Management, 21(5),591-624. https://doi.org/10.1108/09564231011079066

Floyd, S.W. \& Lane, P.J. (2000). Strategizing Throughout the Organization: Managing Role Conflict in Strategic Renewal. Academy of Management Review 25,154-177. https://doi.org/10.2307/259268

Gatignon, H. \& Xuereb, J. M. (1997). Strategic orientation of the firm and new product performance. Journal of Marketing Research, 34 (1), 77-90. https://doi.org/10.2307/3152066

Gibson, C. B., \& Birkinshaw, J. (2004). The antecedents, consequences, and mediating role of organizational ambidexterity. Academy of Management Journal, 47(2), 209-226. https://doi.org/10.5465/20159573

Girod, S. J., \& Whittington, R. (2016). Reconfiguration, restructuring and firm performance: Dynamic capabilities and environmental dynamism. Strategic Management Journal 38(5),1121-1133. https://doi.org/10.1002/smj.2543

Goel, S. \& Jones III1, J.R. (2016). Entrepreneurial Exploration and Exploitation in Family Business: A Systematic Review and Future Directions, Family Business Review, 29(1), 1-27. https://doi.org/10.1177/0894486515625541

Gomes, G. \& Wojahn, R. M. (2017) Organizational learning capability, innovation and performance: study in small and medium-sized enterprises (SMES), Revista de Administração 52, 163-175. https://doi.org/10.1016/j. rausp.2016.12.003

Grant, R.M. (1991) The Resource-Based Theory of Competitive Advantage: Implications for Strategy Formulation. California Management Review 33, 114-35. https://doi.org/10.2307/41166664

Griffith, D. A., \& Harvey, M. G. (2001). A resource perspective of global dynamic capabilities. Journal of International Business Studies, 32(3), 597-606. https://doi.org/10.1057/palgrave.jibs. 8490987

Gunday, G., Ulusoy, G., Kilic, K., \& Alpkan, L. (2011). Effect of innovation type on firm performance. International Journal of Marketing, G2, 30-34.

Gupta, A. K., Smith, K. G., \& Shalley, C. E. (2006). The interplay between exploration and exploitation. Academy of Management Journal 49, 693-706. https://doi.org/10.5465/amj.2006.22083026

Hacklin, F. , Bjorkdahl, J.\& Wallin, M.W. (2018). Strategies for business model innovation: How firms reel in migrating value, Long Range Planning, 51(1),82-110. https://doi.org/10.1016/j.lrp.2017.06.009

Haleblian, J., Mcnamara Kolev, G.K., Dykes, B.J., (2012). Exploring firm characteristics that differentiate leaders from followers in industry merger waves: a competitive dynamics perspective. Strategic Management Journal 33(9), 1037-1052. https://doi.org/10.1002/smj.1961

Helfat, C. E., \& Peteraf, M. A. (2003). The dynamic resource-based view: capability lifecycles. Strategic Management Journal, 24(10), 997-1010. https://doi.org/10.1002/smj.332

Helfat, C. E., \& Winter, S. G. (2011). Untangling dynamic and operational capabilities: Strategy for the (N)ever-changing world. Strategic Management Journal 32 (11), 1243-1250. https://doi.org/10.1002/smj.955

Hendry, C., \& J. Brown. (2006). Organizational Networking in UK Biotechnology Clusters. British Journal of Management 17 (1), 55-73. https://doi.org/10.1111/j.1467-8551.2005.00464.x

Hair Jr., J.F., Black, W.C., Babin, B.J., Anderson, R.E. and Tatham, R.L. (2006). Multivariate Data Analysis, 6th ed., Pearson-Prentice Hall, Upper Saddle River, NJ. 
Hao, S. \& Song, M. (2016). Technology-driven strategy and firm performance: Are strategic capabilities missing links? Journal of Business Research, 69(2), 751-759. https://doi.org/10.1016/j.jbusres.2015.07.043

He, Z.L., \& Wong, P.K. (2004). Exploration vs. exploitation: An empirical test of the ambidexterity hypothesis. Organization Science 15(4), 481-494. https://doi.org/10.1287/orsc.1040.0078

Helfat,C.E. \& ,Martin, J.A.,(2015).Dynamic capbilities:review and assessment of managerial impact on strategic change. Journal of Management 41(5),1281-1312 https://doi.org/10.1177/0149206314561301

Helfat, C., \& Peteraf, M. (2009). Understanding dynamic capabilities: Progress along a developmental path. Strategic Organization, 7(1), 91-102. https://doi.org/10.1177/1476127008100133

Helfat, C. and Peteraf, M., (2003). The Dynamic Resource-Based View: Capability Lifecycles. Strategic Management Journal, 24(10), 997-1010. https://doi.org/10.1002/smj.332

Helfat, C. E., Finkelstein, S., Mitchell, W., Peteraf, M. A., Singh, H., Teece, D. J., \& Winter, S. G. (2007). Dynamic capabilities. Understanding strategic change in organizations. Malden, MA: Blackwell Publishing.

Hitt, A., Dacin, M., Levitas, E., Arregle, J. and Borza, A. (2000), Partner selection in emerging and developed market contexts: resource based and organizational learning perspectives, Academy of Management Journal, 43(3), 44967. https://doi.org/10.5465/1556404

Holmqvist, M. (2004). Experiential learning processes of exploitation and exploration within and between organizations: An empirical study of product development. Organization Science 15(1), 70-81. https://doi.org/10.1287/ orsc. 1030.0056

Homburg, C., Grozdanovic, M., \& Klarmann, M. (2007). Responsiveness to customers and competitors: The role of affective and cognitive organizational systems. Journal of Marketing, 71 (3),18-38 https://doi.org/10.1509/ jmkg.71.3.18

Ho, L. A. (2008), What affects organizational performance? The linking of learning and knowledge management, Industrial Management \& Data Systems, 108(9), 1234-1254 https://doi.org/10.1108/02635570810914919

Hooley, G.J., Greenley, G., Cadogan, J.W., \& Fahy, J. (2005) The performance impact of marketing resources. Journal of Business Research 58(1), 18-27. https://doi.org/10.1016/s0148-2963(03)00109-7

Hult, G., Ketchen, D. \& Slater, S. (2005). Market orientation and performance: an integration of disparate approaches. Strategic Management Journal, 26(12), 1173-1181. https://doi.org/10.1002/smj.494

Isobe, T., S. Makino, \& D. B. Montgomery. (2004). Exploitation, Exploration, and Firm Performance: The Case of Small Manufacturing Firms in Japan. Research Collection. Lee Kong Chian School of Business, Singapore.

Izadi, S. A. \&Ahmadian, S. (2018). The Effects of Strategic Orientation and Firm Competencies on Export Performance, Revista Publicando, 5(15),834-857.

Jansen, J.J.P., Van den Bosch, F.A.J., \& Volberda, H.W. (2006). Exploratory innovation, exploitative innovation, and performance: effects of organizational antecedents and environmental moderators. Management Science, 52(11),1661-1674. https://doi.org/10.1287/mnsc.1060.0576

Jiao, H., Alon, I, Kwon, C. \& YuCu, K. Y. (2013). When should organizational change be implemented? The moderating effect of environmental dynamism between dynamic capabilities and new venture performance, Journal of Engineering and Technology Management, 30(2),188-205. https://doi.org/10.1016/j.jengtecman.2013.01.005

Katila, R.\& Ahuja, G. (2002). Something old, something new: A longitudinal study of search behavior and new product introduction. Academy of Management Journal, 45(6),1183-1194. https://doi.org/10.2307/3069433

Kearney, A., Harrington, D., Kelliher, F., (2014). Exploiting managerialcapability for innovation in a micro-firm context. European Journal of Training and Development 38(1/2),95-117. https://doi.org/10.1108/ejtd-11-2013-0122

Kim, N., \& Atuahene-Gima, K. (2010). Using exploratory and exploitative market learning for new product development. Journal of Product Innovation Management, 27, 519-536. https://doi.org/10.1111/j.1540-5885.2010.00733.x

Kohli, A.K. and Jaworski, B.J. (1990). Market Orientation: The Construct, Research Propositions and Managerial Implications, Journal of Marketing, 54(2), 1-18. https://doi.org/10.2307/1251866

Koryak, O., Lockett, A. , Haytonb, J., Nicolaou, N., \& Mole, K. (2018).Disentangling the antecedents of ambidexterity: Exploration and exploitation, Research Policy 47(2),413-427 https://doi.org/10.1016/j.respol.2017.12.003

Kor, Y.Y., (2006). Direct and interaction effects of top manage-ment team and board compositions on R\&D investment strategy. Strategy Management Journal, 27(11),1081-1099. https://doi.org/10.1002/smj.554 
Kor, Y.,\& Mesko, A., (2013). Dynamic managerial capabilities: configu-ration and orchestration of top executives' capabilities and thefirm's dominant logic. Strategy Management Journal 34(2), 233-244.

Kumar, K., Subramanian, R. \& Strandholm, K. (2011). Market orientation and performance: Does organizational strategy matter? Journal of Applied Business Research, 18(1),778-794 https://doi.org/10.19030/jabr.v18i1.2099

Kuo, S.-Y., Lin, P.-C .\& Lu, C.-S. (2017). The effects of dynamic capabilities, service capabilities, competitive advantage, and organizational performance in container shipping. Transportation Research Part A 95, 356-371. https:// doi.org/10.1016/j.tra.2016.11.015

Lado, A., Boyd, N., \& Wright, P. (1992). A competency based model of sustainable competitive advantage: Toward a conceptual integration. Journal of Management 18,77-91. https://doi.org/10.1177/014920639201800106

Lado, A.A.,Wilson,M.C.,(1994).Human resource systems and sustained competitive advantage: a competency-based perspective. The Academy of Management Review, 19(4), 699-727. https://doi.org/10.5465/amr.1994.9412190216

Langerak, F., Hultink, E. J. \& Robben, H. S. J (2004). The impact of market orientation, product advantage, and launch proficiency on new product performance and organizational performance. Journal of Product Innovation Management, 21, 79-94. https://doi.org/10.1111/j.0737-6782.2004.00059.x

Lawson, B., Samson, D., (2001). Developing innovation capability in organisations: a dynamic capabilities approach. International Journal of Innovation Management, 5(3), 377-400. https://doi.org/10.1142/s1363919601000427

Lau, C. (2011). Team and organizational resources, strategic orientations and firm performance in a transitional economy. Journal of Business Research, 64,1344-1351. https://doi.org/10.1016/j.jbusres.2011.01.001

Lavie, D., Kang, J. and Rosenkopf, L. (2011). Balance Within and Across Domains: The Performance Implications of Exploration and Exploitation in Alliances. Organization Science 22, 1517-1538. https://doi.org/10.1287/ orsc. 1100.0596

Lavie, D., Stettner, U., \& Tushman, M. L. (2010). Exploration and exploitation within and across organizations. Academy of Management Annals 4,109-155. https://doi.org/10.1080/19416521003691287

Lavie, D., \& Rosenkopf, L. (2006). Balancing Exploration and Exploitation in Alliance Formation, Academy of Management Journal, 49(2), 797-818. https://doi.org/10.5465/amj.2006.22083085

Levinthal, D., and J. March. (1993). "The Myopia of Learning.” Strategic Management Journal, 14, 95-112. https:// doi.org/10.1002/smj.4250141009

Li, T., \& Calantone, R. J. (1998). The impact of market knowledge competence on new product advantage: conceptualization and empirical examination. Journal of Marketing 62,13-29 https://doi.org/10.2307/1252284

Li, Y., Vanhaverbeke, W., \& Schoenmakers, W. (2008). Exploration and exploitation in innovation: Reframing the interpretation. Creativity and Innovation Management 17(2), 107-126. https://doi.org/10.1111/j.14678691.2008.00477.x

Lisboa, A.,, Skarmeas, D. \& Lages, C. (2012). Innovative capabilities: Their drivers and effects on current and future performance. Journal of Business Research 64,1157-1161. https://doi.org/10.1016/j.jbusres.2011.06.015

Lin, H., McDonough, E.F., Lin, S. \& Lin, C.Y. (2013) Managing the Exploitation/Exploration Paradox: The Role of a Learning Capability and Innovation Ambidexterity. Journal of Product Innovation Management 30, 262-78. https://doi.org/10.1111/j.1540-5885.2012.00998.x

Liu, L.-L., Yen, H.H., Lo, C.-F., \& Chen, C.-Y. (2014). Risk communication, trust and patient commitment. Journal of Accounting, Finance \& Management Strategy, 9(1), 89-114.

Lloréns Montes, F. J., Ruiz Moreno, A., \& Miguel Molina Fernández, L. (2004). Assessing the organizational climate and contractual relationship for perceptions of support for innovation. International Journal of Manpower, 25(2),167-180. https://doi.org/10.1108/01437720410535972

Lorenzo, J. R. F. Rubio, M. T. R. \& Garcés, S.A, (2018). The competitive advantage in business, capabilities and strategy. What general performance factors are found in the Spanish wine industry? Wine Economics and Policy 7(2), 94-108. https://doi.org/10.1016/j.wep.2018.04.001

Mahoney, J.T. (1995). The Management of Resources and the Resource of Management. Journal of Business Research, 33(9), 1-10.

March, J.G. (1991). Exploration and Exploitation in Organizational Learning. Organization Science 2, 71-87. https:// doi.org/10.1287/orsc.2.1.71 
Marín-Idárraga, D. A., González, J.M.H. \& Medina, C. C.(2015). The Antecedents of Exploitation- Exploration and Their Relationship with Innovation: A Study of Managers' Cognitive Maps, Creativity and Innovation Management 2, 1-21

Markides, C. (2013). Business model innovation: what can the ambidexterity literature teach us? Academy Management Perspectives, 27(4), 313-323. https://doi.org/10.5465/amp.2012.0172

Martin, J. A. (2011). Dynamic managerial capabilities and the multi business team: the role of episodic teams in executive leadership groups. Organization Science, 22(1), 118-140. https://doi.org/10.1287/orsc.1090.0515

Massa, L., Tucci, C. \& Afuah, A., (2017). A critical assessment of business model research. Academy of Management Annals 11(1), https://doi.org/10.5465/annals.2014.0072

McGrath, R.G. (2001). Exploratory learning, innovative capacity, and managerial oversight. Academy of Management Journal, 44(1),118-131. https://doi.org/10.5465/3069340

Merrilees, B., Thiele, S.R. and Lye, A. (2011). Marketing capabilities: antecedents and implications for B2B SME performance, Industrial Marketing Management, 40(3), 368-375. https://doi.org/10.1016/j.indmarman.2010.08.005

Mikalef, P. \& Pateli, A. (2017). Information technology-enabled dynamic capabilities and their indirect effect on competitive performance: Findings from PLS-SEM and fsQCA. Journal of Business Research, 70, 1-16. https://doi. org/10.1016/j.jbusres.2016.09.004

Molina-Castillo, F.-J., Jimenez-Jimenez, D., \& Munuera-Aleman, J.-L. (2011). Product competence exploitation and exploration strategies: The impact on new product performance through quality and innovativeness. Industrial Marketing Management 40,1172-1182 https://doi.org/10.1016/j.indmarman.2010.12.017

Mom, T. J., F. A. Van Den Bosch, and H. W. Volberda. (2007). Investigating Managers' Exploration and Exploitation Activities: The Influence of Top-down, Bottom-up, and Horizontal Knowledge Inflows. Journal of Management Studies, 44(6), 910-931. https://doi.org/10.1111/j.1467-6486.2007.00697.x

Mone, M, McKinley, W \& Barker, V, (1998). Organizational decline and innovation: A contingency Framework, Academy of Management Review, 23(1),115-132. https://doi.org/10.2307/259102

Morales, García-V. J., Ruiz-Moreno, A., \& Llorens-Montes, F. J.(2007). Effects of technology absorptive capacity and technology proactivity on organizational learning, innovation and performance: an empirical examination. Technology Analysis \& Strategic Management, 19(4), 527-558. https://doi.org/10.1080/09537320701403540

Morgan, N. A., Zou, S., Vorhies, D. W., \& Katsikeas, C. S. (2003). Experiential and informational knowledge, architectural marketing, capabilities, and the adaptive performance of export ventures. Decision Sciences, 34(2),287-321. https://doi.org/10.1111/1540-5915.02375

Motwani, J., Dandridge, T., Jiang, J. and Soderquist, K. (1999). Managing innovation in French small and medium-sized enterprises. Journal of Small Business Management, 37(2),106-114.

Nasution, H., Mavondo, F., Matanda, M. \& Ndubisi, N. (2011). Entrepreneurship: Its relationship with market orientation and learning orientation and as antecedents to innovation and customer value. Industrial Marketing Management, 40, 336-345. https://doi.org/10.1016/j.indmarman.2010.08.002

Narver, J. C. \& S. F. Slater (1990). The Effect of a Market Orientation on Business Profitability, Journal of Marketing, 54(4), 20-35.

Ngo, L.V., and O'Cass, A. (2013). Innovation and business success: The mediating role of customer participation. Journal of Business Research, 66,1134-1142. https://doi.org/10.1016/j.jbusres.2012.03.009

Nielsen, B. B. (2010a). Multilevel issues in strategic alliance research. In T. K. Das (Ed.), Researching strategic alliances: Emerging issues. Charlotte, NC: Information Age Publishing.

Nielsen, B. B. (2010b). Strategic fit, contractual and procedural governance in alliances. Journal of Business Research 63,682-689 https://doi.org/10.1016/j.jbusres.2009.05.001

Nilssen, J., Bertheussen, B A., Dreyer, B.(2015). Sustained competitive advantage based on high quality input, Marine Policy 52,145-154. https://doi.org/10.1016/j.marpol.2014.10.011

Noble, C.H., Sinha, R.K. \& Kumar, A. (2002) Market Orientation and Alternative Strategic Orientations: A Longitudinal Assessment of Performance Implications. Journal of Marketing, 66(4), 25-39. https://doi.org/10.1509/ jmkg.66.4.25.18513

O'Cass, A., Heirati, N., \& Ngo, L. V. (2014). Achieving new product success via the synchronization of exploration and exploitation across multiple levels and functional areas. Industrial Marketing Management 43,862-872. https:// 
doi.org/10.1016/j.indmarman.2014.04.015

Olson, E. M., Slater, S. F., \& Hult, T. M. (2005). The performance implications of fit among business strategy, marketing organizations structure, and strategic behaviour. Journal of Marketing 69,49-65. https://doi.org/10.1509/ jmkg.69.3.49.66362

Ozkaya, H. E., Droge, C., Hult, G. T. M., Calantone, R., \& Ozkaya, E. (2015). Market orientation, knowledge competence, and innovation. International Journal of Research in Marketing, 32(3), 309-318. https://doi.org/10.1016/j. ijresmar.2014.10.004

O’Reilly, C. A., and M. L. Tushman (2008). Ambidexterity as a Dynamic Capability: Resolving the Innovator's Dilemma. Research in Organizational Behaviour 28,185-206. https://doi.org/10.1016/j.riob.2008.06.002

O'Reilly III, C., \& Tushman, M. (2011). Organizational ambidexterity in action: how managers explore and exploit. California Management Review, 53(4), 5-22. https://doi.org/10.1525/cmr.2011.53.4.5

Ortega,M.J.,(2010).Competitive strategies and firm performance: technological capabilities' moderating roles. Journal of Business Research 63(12),1273-1281. https://doi.org/10.1016/j.jbusres.2009.09.007

Ozkaya, H. E., Droge, C., Tomas, G., Hult, M., Calantone, R., \& Ozkaya, E. (2015). Market orientation, knowledge competence, and innovation. International Journal of Research in Marketing, 32(3),309-318. https://doi.org/10.1016/j.ijresmar.2014.10.004

Pavlou, P. A., \& El Sawy, O. A. (2006). From IT leveraging competence to competitive advantage in turbulent environments: The case of new product development. Information Systems Research, 17, 198-227. https://doi. org/10.1287/isre.1060.0094

Pavlou, P. A., \& El Sawy, O. A. (2011). Understanding the elusive black box of dynamic capabilities. Decision Sciences, 42, 239-273. https://doi.org/10.1111/j.1540-5915.2010.00287.x

Pearson, J., Pitfield, D. \& Ryley, T. (2015). Intangible resources of competitive advantage: Analysis of 49 Asian airlines across three business models. Journal of Air Transport Management, 47, 179-189. https://doi.org/10.1016/j. jairtraman.2015.06.002

Pezeshkan, A., Fainshmidt, S., Nair, A., Frazier, M. L., \& Markowski, E. (2016). An empirical assessment of the dynamic capabilities-performance relationship. Journal of Business Research, 69, 2950-2956. https://doi. org/10.1016/j.jbusres.2015.10.152

Pickett,L.,(1998).Competencies and managerial effectiveness :putting competencies to work.

Public Personnel Management, 27(1),103-115 https://doi.org/10.1177/009102609802700110

Podsakoff, P.M. and Organ, D.W. (1986). Self-reports in organizational research: problems and prospects, Journal of Management, 12(4), 69-82. https://doi.org/10.1177/014920638601200408

Podsakoff, P.M. and MacKenzie, S.B. (2003). An examination of the psychometric properties and homological validity of some revised and reduced substitutes for leadership scales, Journal of Applied Psychology, 79(5),702-713 https://doi.org/10.1037/0021-9010.79.5.702

Porter, M.E. (1980). Competitive Strategy: Techniques for Analysing Industries and Competitors, The Free Press, New York.

Prange, C. and Verdier, S. (2011). Dynamic Capabilities, Internationalization Processes and Performance. Journal of World Business, 46(1),126-133. https://doi.org/10.1016/j.jwb.2010.05.024

Protogerou, A., Caloghirou, Y., \& Lioukas, S. (2012). Dynamic capabilities and their indirect impact on firm performance. Industrial and Corporate Change 21, 615-647. https://doi.org/10.1093/icc/dtr049

Raisch, S., Zimmermann, A., (2017). A process perspective on the Exploration-Exploitation paradox. The Oxford Handbook of Organizational Paradox. pp. 315.

Raisch, S., Birkinshaw, J., Probst, G., \& Tushman, M. (2009). Organizational ambidexterity: Balancing exploitation and exploration for sustained performance. Organization Science, 20(4), 685-695. https://doi.org/10.1287/ orsc. 1090.0428

Rajapathirana, RP.J. \& Hui, Y. (2018). Relationship between innovation capability, innovation type, and firm performance, Journal of Innovation \& Knowledge 3, 44-55. https://doi.org/10.1016/j.jik.2017.06.002

Rodríguez, N.G., Pérez, J.S., Gutiérrez, J.A.T., (2008). Can a good organizational climate compensate for a lack of top management commitment to new product development? Journal of Business Research 61(2),18-131. https://doi. org/10.1016/j.jbusres.2007.06.011 
Romme, A.G., Zollo, M., Berends, P., (2010). Dynamic capabilities, deliberate learning and environmental dynamism: a simulation model. Industrial Corporate Change 19,1271-1299. https://doi.org/10.1093/icc/dtq031

Rose, R. C., Abdullah, H. and Ismad, A. I. (2010). A Review on the relationship between organizational resources, competitive advantage and performance. The Journal of International Social Research, 3(1), 488-498.

Rosing, K., Frese, M., \& Bausch, A. (2011). Explaining the heterogeneity of the leadership innovation relationship: Ambidextrous leadership. The Leadership Quarterly, 22(5), 956-97. https://doi.org/10.1016/j.leaqua.2011.07.014

Ruiz-Jiménez,J.M \& Fuentes-Fuentes,M-M (2016). Management capabilities, innovation, and gender diversity in the top management team: An empirical analysis in technology-based SMEs, BRQ Business Research Quarterly 19, 107-121. https://doi.org/10.1016/j.brq.2015.08.003

Schilke, O., (2014). On the contingent value of dynamic capabilities for competitive advantage: the nonlinear moderating effect of environmental dynamism. Strategic Management Journal 35, 179-203. https://doi.org/10.1002/ smj.2099

Scott-Kennel, J., \& Giroud, A. (2015). MNEs and FSAs: network knowledge, strategic orientation and performance. Journal of World Business, 50(1), 94-107. https://doi.org/10.1016/j.jwb.2014.02.004

Sanchez, P., Ricart, J.E., (2010). Business model innovation and sources of value creation in low-income markets. European Management Review 7(3),138 -154. https://doi.org/10.1057/emr.2010.16

Shane, S., \& Venkataraman, S. (2000). The promise of entrepreneurship as a field of research. Academy of Management Review 25, 217-226 https://doi.org/10.5465/amr.2000.2791611 .

Sheng,M. L. (2018). A dynamic capabilities-based framework of organizational sensemaking through combinative capabilities towards exploratory and exploitative product innovation in turbulent environments, Industrial Marketing Management 65, 28-38. https://doi.org/10.1016/j.indmarman.2017.06.001

Shiu, E., Pervan, S., Bove, L. and Beatty, S. (2011) Reflections on discriminant validity: reexamining the Bove et al. (2009) findings, Journal of Business Research 64(5), 497-500. https://doi.org/10.1016/j.jbusres.2010.04.004

Schuler, R.S.,Jackson,S.E.,(1987). Linking competitive strategies with human resource management practices. The Academy of Management Executive, 1(3), 207-219. https://doi.org/10.5465/ame.1987.4275740

Sidhu, J.S., Volberda, H.W. \& Commandeur, H.R. (2004). Exploring Exploration Orientation and its Determinants: Some Empirical Evidence. Journal of Management Studies 41,913-32. https://doi.org/10.1111/j.14676486.2004.00460.x

Sidhu, J. S., H. R. Commandeur, \& H. W. Volberda. (2007). The Multifaceted Nature of Exploration and Exploitation: Value of Supply, Demand, and Spatial Search for Innovation. Organization Science 18,20-38. https://doi. org/10.1287/orsc.1060.0212

Sinkovics, R. and Roath, A. (2004). Strategic orientation, capabilities, and performance in manufacturer - 3PL relationships, Journal of Business Logistics, 25(2), 43-64. https://doi.org/10.1002/j.2158-1592.2004.tb00181.x

Sirmon, D.G., \& Hitt, M.A. (2009). Contingencies within dynamic managerial capabilities: Interdependent effects of resource investment and deployment on firm performance. Strategic Management Journal, 30(13),1375-1394. https://doi.org/10.1002/smj.791

Smith, Wendy, \& Tushman, Michael L. (2005). Managing strategic contradictions: a top management model for managing innovation streams. Organization Science 16, 522- 536. https://doi.org/10.1287/orsc.1050.0134

Sulistyo, H. \& Siyamtinah (2016). Innovation capability of SMEs through entrepreneurship, marketing capability, relational capital and empowerment, Asia Pacific Management Review 21(4),1-18. https://doi.org/10.1016/j.apmrv.2016.02.002

Song, X. M., Droge, C., Hanvanich, S., \& Calantone, R. (2005), Marketing and technology resource complementarity: an analysis of their interaction effect in two environmental contexts. Strategic Management Journal, 26(3), 259276. https://doi.org/10.1002/smj.450

Song, M., \& Parry, M. E. (2009). The desired level of market orientation and business unit performance. Journal of the Academy of Marketing Science, 37(2),144-160. https://doi.org/10.1007/s11747-008-0114-0

Striteska, M. \& Jelinkova, L. (2015). Strategic performance management with focus on the customer. Procedia-Social and Behavioral Sciences, 210, 66-76. https://doi.org/10.1016/j.sbspro.2015.11.330

Tabeau, K., Gemserb, G., Hultinka, E. J. \&. Wijnbergc, N.M. (2017). Exploration and exploitation activities for design innovation, Journal of Marketing Management 33, 203-225. 
Teece, D.J. (2018). Business models and dynamic capabilities. Long Range Planning 51, 40-49. https://doi. org/10.1016/j.lrp.2017.06.007

Teece, D. J. (2007). Explicating dynamic capabilities: the nature and micro foundations of (sustainable) enterprise performance. Strategic Management Journal 28, 1319-1350. https://doi.org/10.1002/smj.640

Teece, D., Pisano, G. \& Shuen, A. (1997). Dynamic capabilities and strategic management. Strategic Management Journal 18, 509-533. https://doi.org/10.1002/(sici)1097-0266(199708)18:7<509::aid-smj882>3.0.co;2-z

Thatte, A.A. (2007). Competitive Advantage of A Firm Through Supply Chain Responsiveness and Supply Chain Management Practices, Published PhD Dissertation, University of Toledo

Thornhill, S. (2006). Knowledge, Innovation and firm performance in high and low technology regimes. Journal of Business Venturing 21, 687-703. https://doi.org/10.1016/j.jbusvent.2005.06.001

Tutar, H., Nart, S., \& Bingöl, D. (2015). The Effects of Strategic Orientations on Innovation Capabilities and Market Performance: The Case of ASEM. Procedia- Social and Behavioral Sciences 207,709-719. https://doi. org/10.1016/j.sbspro.2015.10.144

Varadarajan, P., \& Clark, T. (1994). Delineating the scope of corporate, business, and marketing strategy. Journal of Business Research 31, 93-105. https://doi.org/10.1016/0148-2963(94)90074-4

Vokurka, R. J., Zank, G. M., and Lund III, C. M. (2002). Improving Competitiveness through Supply Chain Management: A Cumulative Improvement Approach, Competitiveness Review, 12 (1),14-25. https://doi.org/10.1108/ eb046431

Wang, X, \& Dass, M. (2017). Building innovation capability: The role of top management innovativeness and relative-exploration orientation. Journal of Business Research 76,127-135 https://doi.org/10.1016/j.jbusres.2017.03.019

Wang, H., and J. Li. (2008). Untangling the Effects of Over exploration and Overexploitation on Organizational Performance: The Moderating Role of Environmental Dynamism. Journal of Management 34(5), 925-951. https:// doi.org/10.1177/0149206308321547

Wang, Y., \& Lo, H. (2003). Customer-focused performance and the dynamic model for competence building and leveraging: a resource-based view. Journal of Management Development 22(6), 483 - 526. https://doi. org/10.1108/02621710310478486

Welter, C.,Bosse,D.A.,Alvarez,S.A.,(2013).The interaction between Managerial and technological capabilities as a determinant of company performance: an empirical study of biotech firms. International Journal of Management 30(1), 263-272.

Wilden, R., Gudergan, S.P., Nielsen, B.B., Lings, L., (2013). Dynamic capabilities and performance: strategy, structure and environment. Long Range Planning 46, 72-96. https://doi.org/10.1016/j.lrp.2012.12.001

Wingwon, \& Boonthawan. (2012). Effects of entrepreneurship, organization capability, strategic decision making and innovation toward the competitive advantage of SMEs enterprise. Journal of Management and Sustainability 2(1), 137-150.

Winter, S. (2003). Understanding dynamic capabilities. Strategic Management Journal 24(10), 991-995. https://doi. org/10.1002/smj.318

Wu, L. Y. (2007). Entrepreneurial resources, dynamic capabilities and start-up performance of Taiwan's high-tech firms. Journal of Business Research 60(5), 549-555. https://doi.org/10.1016/j.jbusres.2007.01.007

Yalcinkaya, G., R. J. Calantone, and D. A. Griffith. (2007). An Examination of Exploration and Exploitation Capabilities: Implications for Product Innovation and Market Performance. Journal of International Marketing 15, 63-93. https://doi.org/10.1509/jimk.15.4.63

Yamakawa, Y., H. Yang, and Z. Lin. (2011). Exploration versus Exploitation in Alliance Portfolio: Performance Implications of Organizational, Strategic, and Environmental Fit. Research Policy 40, 287-296. https://doi. org/10.1016/j.respol.2010.10.006

Yang, T. T., \& C. R. Li. (2011). Competence Exploration and Exploitation in New Product Development: The Moderating Effects of Environmental Dynamism and Competitiveness. Management Decision 49(9),1444-1470. https:// doi.org/10.1108/00251741111173934 
Yang, Y., Wang, Q., Zhu, H. \& Wu, G. (2012). What are the effective strategic orientation for new product success under different environment? An empirical study of Chinese businesses. Journal Production Innovation Management 29(2),166-179. https://doi.org/10.1111/j.1540-5885.2011.00900.x

Zhou, K.Z., Yim, C.K. \& Tse, D.K. (2005). The effects of strategic orientations on technology- and market-based breakthrough innovations. Journal of Marketing 69(2), 42-60. https://doi.org/10.1509/jmkg.69.2.42.60756

Zollo, M., \& Winter, S. G. 2002. Deliberate learning and the evolution of dynamic capabilities. Organization Science 13(3),339-351. https://doi.org/10.1287/orsc.13.3.339.2780

Zott, C., (2003). Dynamic capabilities and the emergence of intra industry differential firm performance: Insights from a simulation study. Strategic Management Journal 24(2), 90-97. https://doi.org/10.1002/smj.288

Zott, C., Amit, R. \& Massa, L., (2011). The business model: recent developments and future research. Journal of Management 37(4),1019-1042. https://doi.org/10.1177/0149206311406265 